\title{
A NEW SPECIES OF ARTIGASIA CHRISTIE, 1934 (THELASTOMATOIDEA: HYSTRIGNATHIDAE) FROM CUBA, AND REDESCRIPTION OF ARTIGASIA SIMPLICITAS GARCÍA ET COY, 1995
}

\author{
Jans Morffe Rodríguez and Nayla García Rodríguez \\ Instituto de Ecología y Sistemática. Carretera de Varona $\mathrm{km} \mathrm{3}^{1}{ }_{2}$, Capdevila, Boyeros, Ciudad de La \\ Habana,Cuba.jans@ecologia.cu,nayla@ecologia.cu
}

\begin{abstract}
A new species of Artigasia Christie, 1934 (Thelastomatoidea: Hystrignathidae) parasiting Passalus pertyi (Coleoptera: Passalidae) is described from La Habana province, Cuba. A. gunnaryae sp. nov. is characterized by having two cephalic annules, spines from the end of second cephalic annule to the end of procorpus, absence of lateral alae, distal flexure of the ovary very short and ridged eggs. Artigasia simplicitas García et Coy, 1995 is redescribed and an emended diagnosis is given. A new morph of this species is described for La Habana province. A comparative table with the measurements of both morphs is given.
\end{abstract}

Key words: Nematoda, Hystrignathidae, Passalidae, Artigasia, Passalus, new species, redescription, Cuba.

\section{RESUMEN}

Se describe una nueva especie de Artigasia Christie, 1934 (Thelastomatoidea: Hystrignathidae) parásita de Passalus pertyi (Coleoptera: Passalidae) de La Habana, Cuba. $A$. gunnaryae sp. nov. se caracteriza por la presencia de dos anillos cefálicos, espinas desde el final del segundo anillo cefálico hasta el final del cuerpo esofágico, ausencia de alas laterales, flexión distal del ovario muy corta y huevos estriados. Se redescribe y rediagnostica Artigasia simplicitas García et Coy, 1995. Se describe un nuevo morfo de esta especie para la provincia La Habana. Se ofrece una tabla comparativa con las medidas de ambos morfos.

Palabras clave: Nematoda, Hystrignathidae, Passalidae, Artigasia, Passalus, especie nueva, redescripción, Cuba.

\section{INTRODUCTION}

Passalid beetles are common hosts of nematodes belonging to the family Hystrignathidae (Oxyurida: Thelastomatoidea). The genus Artigasia Christie, 1934 is the largest among Hystrignathidae. It was erected to include those species with spines in the cervical cuticle, procorpus clavate and females with monodelphic and prodelphic genital tract (Adamson and Van Waerebeke, 1992).

Most Artigasia species were described for Brazil (Artigas, 1926; Travassos and Kloss, $1957 \mathrm{a}, 1957 \mathrm{~b}$; 1958). However, the descriptions and line drawings given by these authors are inaccurate (Hunt, 1981), and revision and redescription of these materials are needed.

Théodoridès $(1955,1958)$ and Van Waerebeke (1973) studied the African Artigasia with the description of 16 species. The last author emphasized the value of the number of rows of spines, their disposition and the shape of the cephalic end as important features for identification.

Hunt (1981) described A. horridospina Hunt, 1981 and A. monodelpha (Hunt, 1981) for the Lesser Antilles. In Cuba only two species are described: A. simplicitas García et Coy, 1995 and $A$. melba García, Ventosa et Morffe, 2009 (García and Coy, 1995; García et al., 2009).

The aim of this paper is to describe a new species of Artigasia from Passalus pertyi from La Habana province, Cuba and to redescribe $A$. simplicitas. 


\section{MATERIALS AND METHODS}

Two specimens of Passalus pertyi Kaup, 1869 were collected by hand from rotting logs from La Jaula, San José de las Lajas, La Habana province, Cuba. They were maintained alive in jars and fed with moistened wood chips until dissection. Hosts were anaesthetized with ethyl ether and immediately dissected. Intestines were extracted and dissected in Petri dishes with isotonic saline solution. Parasites were removed and killed with hot water $\left(60-70^{\circ} \mathrm{C}\right)$ and then fixed and conserved in $70 \%$ ethanol.

Nematodes were clear-mounted on glass slides with glycerine and the edges of the coverslips sealed with nail polish to avoid hydration of glycerine (Jex et al., 2004). Measurements were taken as indicated in Travasos and Kloss (1958). They were taken with an ocular micrometer and are given in millimeters. The De Man's ratios a, b, c and V\% were calculated (De Man, 1884). For each variable the range and in parentheses the median plus standard deviation is given. Micrographs were taken with an AxioCam digital camera attached to a Carl Zeiss AxiosKop 2 Plus compound microscope. Line drawings were made with the softwares CorelDRAW 13 and Adobe Photoshop CS2 using micrographs as templates. The scales of all plates are given in millimeters.

The material is deposited in the Colección Helmintológica of the Colecciones Zoológicas (CZACC) from the Instituto de Ecología y Sistemática, Havana, Cuba.

\section{RESULTS}

\section{SYSTEMATICS}

Family Hystrignathidae Travassos, 1920

Genus Artigasia Christie, 1934

Artigasia gunnaryae sp. nov.

(Fig. 1 A-G, Fig. 3 A-C)

Diagnosis. Two cephalic annules, the first one hardly inflated, about one head-length long. Second cephalic annule slightly more inflated, of about same length than the latter. Spines small, arranged in longitudinal rows from the end of second cephalic annule to the end of procorpus. Lateral alae absent. Distal flexure of ovary very short. Eggs with longitudinal ridges.

Diagnosis. Dos anillos cefálicos, el primero apenas dilatado con aproximadamente el largo de la cabeza. Segundo anillo cefálico ligeramente más dilatado, con aproximadamente el mismo largo del primero. Espinas pequeñas, dispuestas en hileras longitudinales, desde el final del segundo anillo cefálico hasta el final del cuerpo esofágico. Alas laterales ausentes. Flexión distal del ovario muy corta. Huevos con crestas longitudinales.

Measurements. Holotype female, $\mathrm{a}=15.47, \mathrm{~b}=7.28, \mathrm{c}=3.93, \mathrm{~V} \%=46.46$, total length $=2.475$, maximum body width $=0.160$, stoma length $=0.045$, procorpus length $=0.235$, isthmus length $=$ 0.038 , diameter of basal bulb $=0.068$, total length of esophagus $=0.340$, nerve ring to anterior end $=$ 0.168 , excretory pore to anterior end $=0.530$, vulva to posterior end $=1.325$, anus to posterior end $=$ 0.630, eggs $=(n=3) 0.113-0.118 \times 0.045-0.055(0.115 \pm 0.003 \times 0.050 \pm 0.005)$.

Paratype females, $(\mathrm{n}=3): \mathrm{a}=17.31-18.04(17.73 \pm 0.38), \mathrm{b}=7.03-7.58(7.27 \pm 0.28), \mathrm{c}=3.91$ $4.43(4.25 \pm 0.30), \mathrm{V} \%=44.00-50.50(47.79 \pm 3.38)$, total length $=2.250-2.525(2.425 \pm 0.152)$, maximum body width $=0.130-0.140(0.137 \pm 0.006)$, stoma length $=0.045$, procorpus length $=$ $0.223-0.238(0.231 \pm 0.008)$, isthmus length $=0.038-0.040(0.039 \pm 0.001)$, diameter of basal bulb $=$ $0.058-0.065(0.062 \pm 0.004)$, total length of esophagus $=0.320-0.350(0.333 \pm 0.015)$, nerve ring to anterior end $=0.150-0.165(0.159 \pm 0.008)$, excretory pore to anterior end $=0.510-0.540(0.527 \pm$ $0.015)$, vulva to posterior end $=1.150-1.400(1.267 \pm 0.126)$, anus to posterior end $=0.510-0.640$ $(0.573 \pm 0.065)$, eggs $=0.110-0.118 \times 0.038-0.055(0.114 \pm 0.003 \times 0.044 \pm 0.006)(n=7)$. 

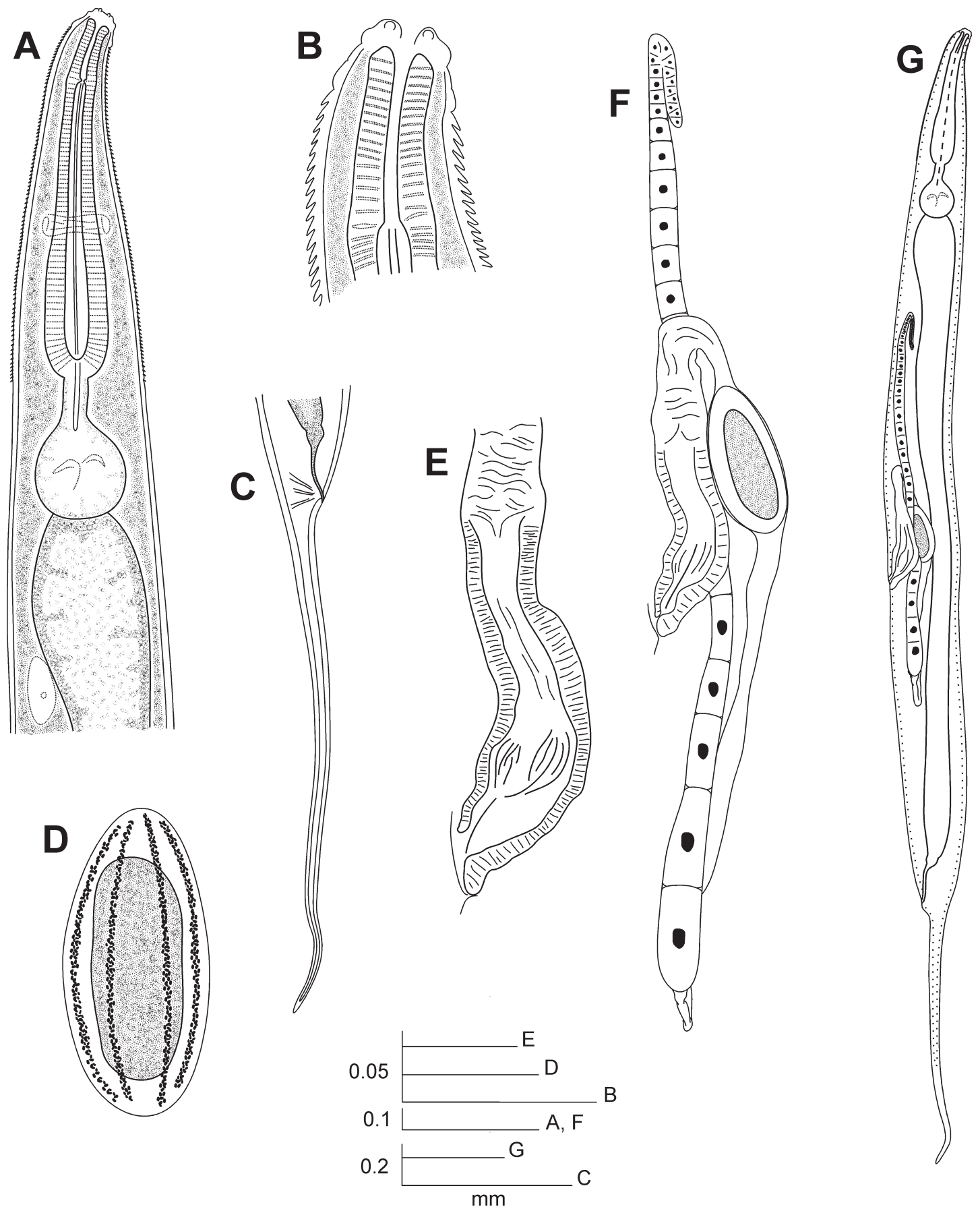

Figure 1. Artigasia gunnaryae sp. nov. Female. A. Esophageal region. B. Cephalic end. C. Tail, lateral view. D. Egg. E. Vulva. F. Genital tract. G. Habitus. 


\section{DESCRIPTION}

Female body comparatively stout. Cuticle annulated in the spiny region and less in the rest of the body. Spines small, arranged in longitudinal rows from the end of the second cephalic annule to the end of procorpus. Longitudinal sub-cuticular striae present. Lateral alae absent. Head bearing eight papillae arranged in pairs and set-off from the rest of body by a single groove. First cephalic annule hardly inflated, about one head-length long. Next to it a second cephalic annule extends slightly more inflated, about same length of the first cephalic annule and set-off from it by a shallow and single groove. Both annules together form a conical structure with a wide and not very deep concavity in its middle. Stoma of about six first annule-lengths long and surrounded by an esophageal collar. Esophagus consists of a muscular procorpus with base markedly clavate and set-off from the isthmus. Basal bulb sub-pyriform with valve plate well developed. Intestine simple, sub-rectilinear with the fore region inflated. Rectum short and anus slightly prominent. Nerve ring encircling the procorpus at about its mid-point. Excretory pore situated at about a bodywidth behind the bulb. Vulva consists of a median transverse slit slightly displaced toward the fore region, with lips not prominent. Genital tract monodelphic, prodelphic. Ovary reflected with a short flexure in their distal end. Eggs in number of two or three by female, ovoid, with eight ridges in the shell. Tail long, conical, attenuated and ending in a fine tip. Male unknown.

Type host. Passalus pertyi Kaup, 1869

Site. Hind gut caeca

Type locality. La Jaula, San José de las Lajas, La Habana province, Cuba

Types. Holotype (female). (CZACC 11.4507) La Jaula, San José de las Lajas, La Habana province, Cuba; en Passalus pertyi; 15/III/2008; E. Fonseca, J. Morffe, G. León y F. Alvarez col. Paratypes (3 females) (CZACC 11.4508-11.4510) same data as holotype.

Etymology. The specific name is a matronymic honouring the colleague and friend Gunnary León Finalé, one of the collectors of the type hosts.

\section{DISCUSSION}

Artigasia gunnaryae sp. nov. is close to $A$. melba by having two cephalic annules and lacking lateral alae. It can be differentiated from the latter species by having the first cephalic annule about one head-length long (in $A$. melba the first cephalic annule has about a half of the head length) and the vulva more posterior $(\mathrm{V} \%=44.0-50.5: 38.9-40.4)$. Both, the esophagus $(b=7.0-7.6: 6.1-6.5)$ and tail $(\mathrm{c}=3.9-4.4: 3.2-3.7)$ are comparatively shorter in A. gunnaryae sp. nov. Artigasia gunnaryae sp. nov. also resembles Artigasia polymorpha Van Waerebeke, 1973 (from Madagascar) from which it differs by having a smaller length of both cephalic annule together $(A$. gunnaryae $=0.013-0.015 ;$ A polymorpha $=0.070)$, the esophagus comparatively shorter $(\mathrm{b}=7.0$ 7.6: 4.7-5.4), the absence of lateral alae and the shorter distal flexure of ovary about half of the body width. In A. polymorpha lateral alae extends from the level of the isthmus to before the anus and the distal flexure of ovary is longer (in the line drawing appears to be about two body-width long).

A. gunnaryae sp. nov. and A. melba are the only Neotropical species bearing more than one cephalic annule. All the species described from Brazil, Mexico and Saint Lucia have one cephalic annule with variable length.

Artigasia simplicitas García et Coy, 1995

(Fig. 2 A-G; Fig 3. D-F)

Artigasia simplicitas García et Coy, 1995: 27-29, fig. 1 a-c.

Diagnosis (emended). Cephalic end with a conical non-spiny region of about 1.5 head-lengths long. Spines small from the end of non-spiny region to the end of procorpus. Lateral alae from the end of spines to less than a body-width before the vulva. Eggs ridged and comparatively large. Tail short. 

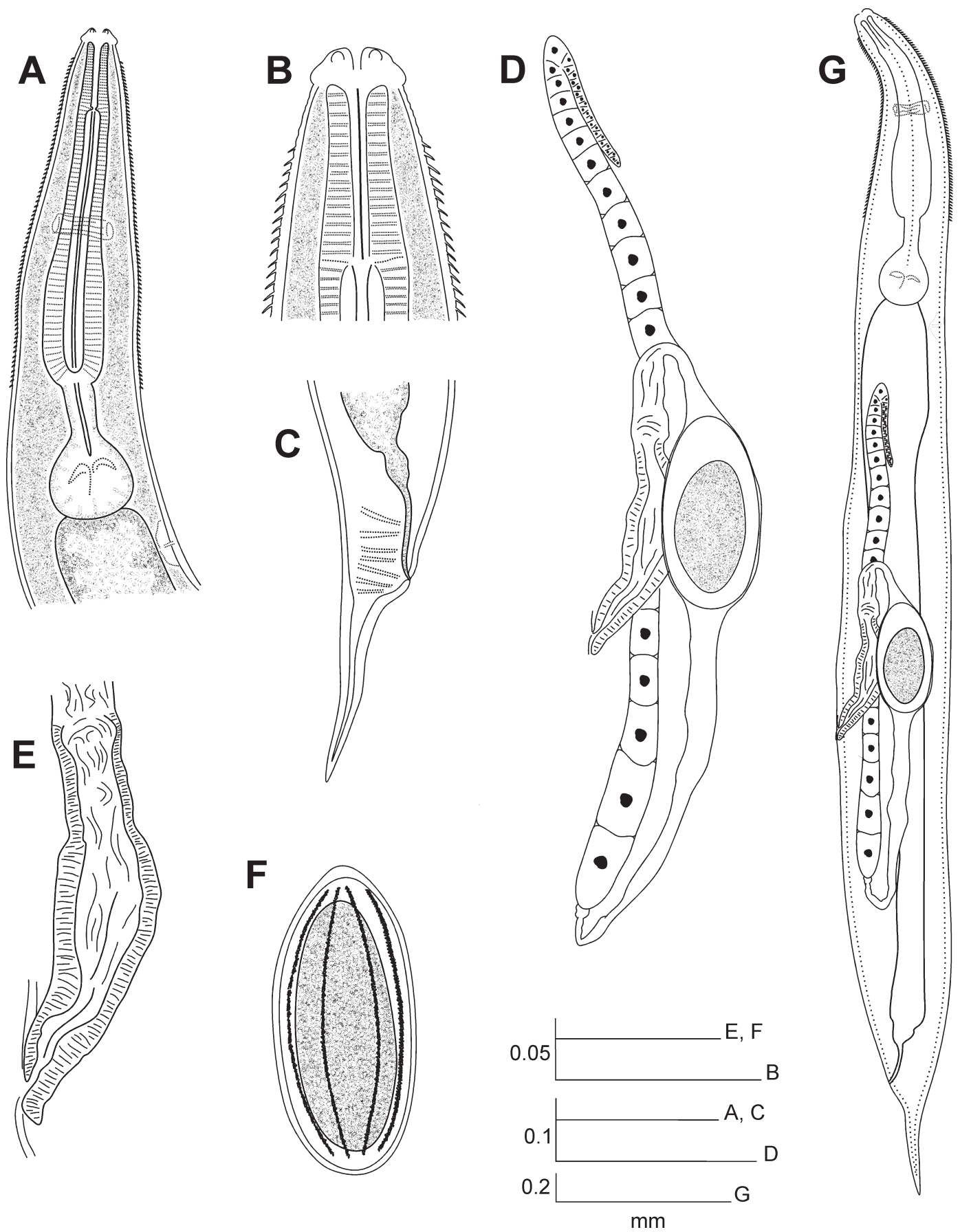

Figure 2. Artigasia simplicitas García et Coy, 1995. Female. A. Esophageal region. B. Cephalic end. C. Tail, lateral view. D. Genital tract. E. Vulva. F. Egg. G. Habitus. 

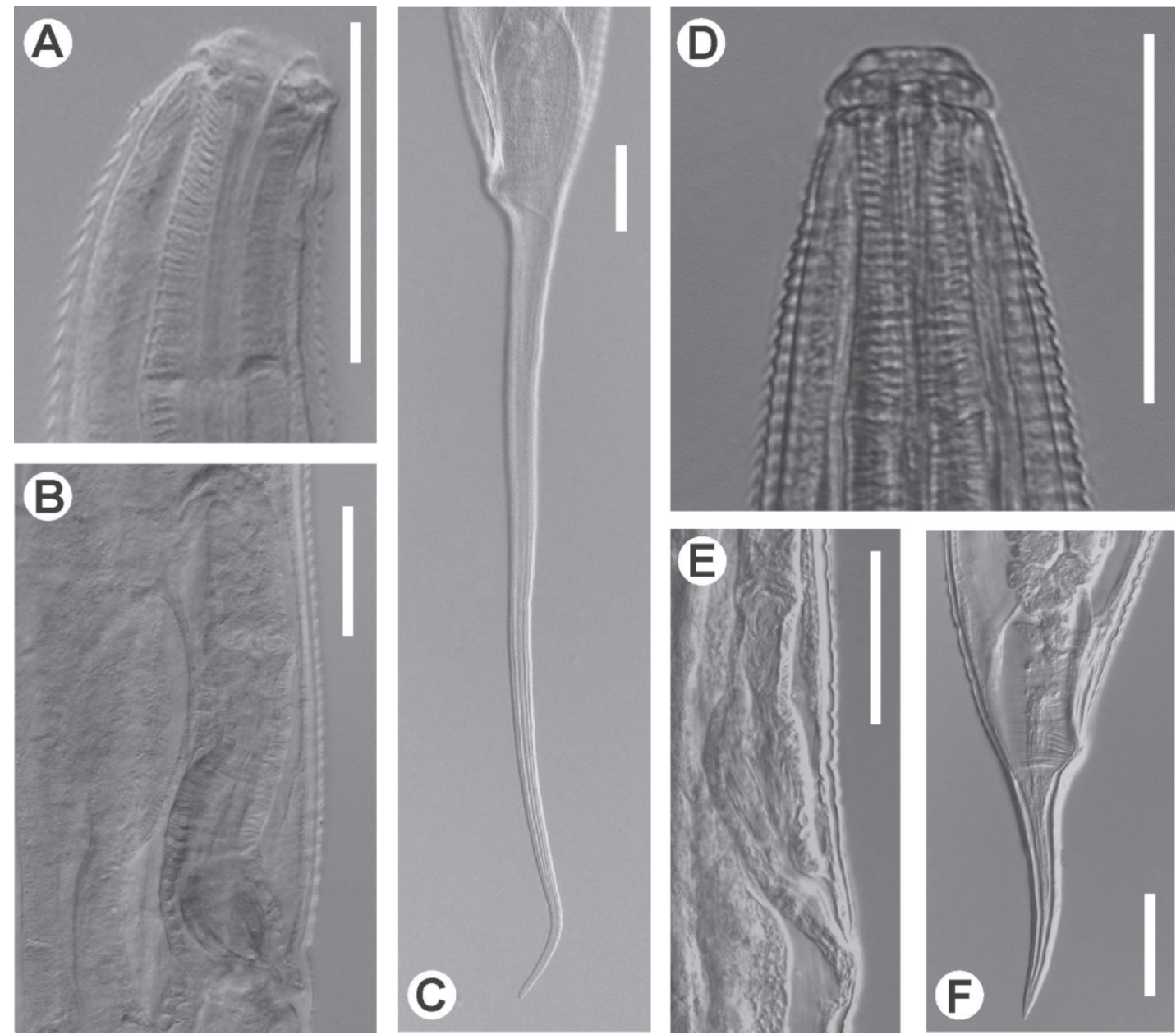

Figure 3. Artigasia gunnaryae sp. nov. Female. A. Cephalic end. B. Vulva and egg. C. Tail, lateral view. Artigasia simplicitas García et Coy, 1995. Female. D. Cephalic end. E. Vulva. F. Tail, lateral view. Scale bars $0.05 \mathrm{~mm}$.

Diagnosis (enmendada). Extremo cefálico con una región inerme y cónica de aproximadamente 1.5 veces la longitud del anillo labial. Espinas pequeñas desde el fin de la región inerme hasta el fin del cuerpo esofágico. Alas laterales desde el fin de las espinas hasta cierta distancia (poco menos del ancho del cuerpo) antes de la vulva. Huevos estriados y relativamente grandes. Cola corta.

Measurements. Holotype (female): $\mathrm{a}=10.13, \mathrm{~b}=5.40, \mathrm{c}=7.04, \mathrm{~V} \%=54.32$, total length $=1,620$, maximum body width $=0.160$, stoma length $=0.045$, procorpus length $=0.220$, isthmus length $=0.033$, diameter of basal bulb $=0.063$, total length of esophagus $=0.300$, nerve ring to anterior end $=0.140$, excretory pore to anterior end $=0.380$, vulva to posterior end $=0.740$, anus to posterior end $=0.230$, eggs $=0.098$ $0.110 \times 0.043-0.050(0.106 \pm 0.006 \times 0.046 \pm 0.003)(n=5)$.

Escaleras de Jaruco population.

Large morph (3 females) $\mathrm{a}=10.93-11.25(11.06 \pm 0.17), \mathrm{b}=5.00-5.14(5.09 \pm 0.08), \mathrm{c}=6.56-7.50$ $(7.08 \pm 0.48), \mathrm{V} \%=55.56-58.54(57.05 \pm 2.11)$, total length $=1.640-1.80(1.697 \pm 0.090)$, maximum body width $=0.150-0.160(0.153 \pm 0.006)$, stoma length $=0.053-0.058(0.055 \pm 0.003)$, procorpus length $=$ $0.238-0.255(0.247 \pm 0.009)$, isthmus length $=0.025-0.030(0.028 \pm 0.003)$, diameter of basal bulb $=0.065$ $0.070(0.068 \pm 0.003)$, total length of esophagus $=0.320-0.350(0.333 \pm 0.015)$, nerve ring to anterior end $=$ $0.168-0.173(0.170 \pm 0.003)$, excretory pore to anterior end $=0.470$, vulva to posterior end $=0.680-0.800$ $(0.740 \pm 0.085)$, anus to posterior end $=0.230-0.250(0.240 \pm 0.010)$, eggs $=0.110 \times 0.045(n=1)$. 
Small morph ( 5 females) $\mathrm{a}=9.08-9.62(9.34 \pm 0.22), \mathrm{b}=4.36-4.85(4.63 \pm 0.24), \mathrm{c}=8.19$ $9.09(8.55 \pm 0.44), \mathrm{V} \%=53.44-60.00(55.76 \pm 2.91)$, total length $=1.090-1.310(1.215 \pm 0.093)$, maximum body width $=0.110-0.140(0.126 \pm 0.011)$, stoma length $=0.040-0.048(0.044 \pm 0.003)$, procorpus length $=0.165-0.190(0.180 \pm 0.010)$, isthmus length $=0.025-0.038(0.031 \pm 0.005)$, diameter of basal bulb $=0.055-0.060(0.058 \pm 0.002)$, total length of esophagus $=0.240-0.270$ $(0.258 \pm 0.013)$, nerve ring to anterior end $=0.118-0.138(0.129 \pm 0.009)$, excretory pore to anterior end $=0.300-0.340(0.324 \pm 0.018)$, vulva to posterior end $=0.490-0.610(0.538 \pm 0.055)$, anus to posterior end $=0.105-0.160(0.135 \pm 0.021)$, eggs $=0.108 \times 0.065(n=1)$.

Description. Female body small, robust and sub-fusiform. Cuticle markedly annulated in the spiny region and less in the rest of the body. Head with eight papillae arranged in pairs and set-off from the body by a single groove. Next to head extends a non-spiny conical region with about 1.5 headlengths long. It is weakly annulated and not inflated. Cervical cuticle armed with small spines from the end of conical region to the end of procorpus. Sub-cuticular longitudinal striae present. Lateral alae strait, extending from the termination of spines to little less than a body-width before the vulva. Stoma extending for about three conical region-lengths long and surrounded by and esophageal collar. Esophagus consisting of a muscular, clavate procorpus, with the base markedly dilated and set-off from the cylindrical isthmus. Basal bulb sub-pyriform. Nerve ring encircling the procorpus at about $45 \%$ of its length. Excretory pore situated at about half of a body-width behind the basal bulb. Intestine simple, sub-rectilinear, its fore region inflated. Rectum short and anus slightly prominent (in the specimens from Escaleras de Jaruco). Vulva consists of a median transverse slit slightly displaced toward the second half of body, its lips slightly prominent. Genital tract monodelphic, prodelphic. Ovary reflected, with the distal flexure short. Eggs comparatively large, ovoid, eight ridges in the shell. Tail very short, conical, subulate, ending in a fine tip.

Table 1. Comparative measurements of females of Artigasia simplicitas García et Coy, 1995 parasites of Passalus interstitialis Escholtz, 1829 from the type locality Hoyo de Jaruco, Sierra de los Organos, Pinar del Río province, Cuba and the two morphs (large and small) found in Escaleras de Jaruco, La Habana province, Cuba.

\begin{tabular}{|l|c|c|c|}
\hline \multicolumn{1}{|c|}{ Measurements } & $\begin{array}{c}\text { Hoyo de Jaruco } \\
\text { (type locality) } \mathrm{n}=1\end{array}$ & $\begin{array}{c}\text { Escaleras de } \\
\text { Jaruco } \\
\text { (large morph) } \\
\mathrm{n}=3\end{array}$ & $\begin{array}{c}\text { Escaleras de Jaruco } \\
\text { (small morph) } \mathrm{n}=5\end{array}$ \\
\hline Total length & 1,620 & $1.640-1.80$ & $1.090-1.310$ \\
Width & 0,160 & $0.150-0.160$ & $0.110-0.140$ \\
Stoma length & 0,045 & $0.053-0.058$ & $0.040-0.048$ \\
Procorpus length & 0,220 & $0.238-0.255$ & $0.165-0.190$ \\
Isthmus length & 0,033 & $0.025-0.030$ & $0.025-0.038$ \\
Basal bulb diameter & 0,063 & 0.0650 .070 & 0.0550 .060 \\
Esophagus length & 0,300 & $0.320-0.350$ & $0.240-0.270$ \\
Nerve ring-head & 0,140 & $0.168-0.173$ & $0.118-0.138$ \\
Excretory pore-head & 0,380 & 0.470 & $0.300-0.340$ \\
Vulva-posterior end & 0,740 & $0.680-0.800$ & $0.490-0.610$ \\
Anus-posterior end & 0,230 & $0.230-0.250$ & $0.105-0.160$ \\
Eggs & $0,108-0,113 \times 0,045-0,050$ & $0.110 \times 0.045$ & $0.108 \times 0.065$ \\
& & $(\mathrm{n}=1)$ & $(\mathrm{n}=1)$ \\
a & 10,13 & $10.93-11.25$ & $9.08-9.62$ \\
$\mathrm{~b}$ & 5,40 & $5.00-5.14$ & $4.36-4.85$ \\
c & 7,04 & $6.56-7.50$ & $8.19-9.09$ \\
V\% & 54,32 & $55.56-58.54$ & $53.44-60.00$ \\
\hline
\end{tabular}




\section{DISCUSSION}

A. simplicitas is close to A. ambri Van Waerebeke, 1973 from which it differs by having a smaller dilation of the posterior part of procorpus, the excretory pore situated to about half of the body-width behind the basal bulb and the extension of lateral alae from the end of spines to less than a body-width before the vulva. In A. ambri the procorpus is markedly clavate at base, the excretory pore is situated at about a body-width behind the basal bulb and the lateral alae start at the level of the excretory pore and end between the vulva and anus. Also, A. simplicitas has the body comparatively stouter $(\mathrm{a}=9.08-11.25: 15.00-19.00)$.

A. simplicitas is similar to A. minuta Travassos et Kloss, 1957 from Brazil, but can be differentiated from it by the form of the cephalic end, the ridged eggs and the smaller extension of lateral alae. The Brazilian species has a short first cephalic annule, eggs smooth and lateral alae extending further down the vulva (Travassos and Kloss, 1957b).

Type host. Passalus interstitialis Escholtz, 1829 (Coleoptera: Passalidae).

Type locality. Hoyo de Jaruco, Viñales, Sierra de los Organos, Pinar del Río province, Cuba.

New record. Escaleras de Jaruco, Jaruco, La Habana province, Cuba.

Material examined. Female holotype (CZACC 11.4246) Hoyo de Jaruco, Viñales, Pinar del Río province, Cuba; H. T. Passalus interstitialis; xi/1991; N. García y J. L. Fontenla col. 8 females (CZACC 11.4511-11.4518) Escaleras de Jaruco, Jaruco, La Habana province, Cuba. Escaleras de Jaruco, Jaruco, La Habana, Cuba; in Passalus interstitialis; 16/iii/2008; E. Fonseca, J. Morffe y F. Alvarez col.

Remarks. A. simplicitas was described from P. interstitialis from Hoyo de Jaruco, Pinar del Río province, Cuba on the basis of two female specimens: holotype and one paratype (García and Coy, 1995). This paratype was misidentified.

In this population from the same host there appear to be two forms morphologically identical, but metrically different. One of them (large morph) agrees in most of the features with the holotype except for the body, stoma, procorpus and esophagus slightly larger (Table 1). The second morph is smaller (body length $=1.090-1.310: 1.640-1.80$ ) and the esophagus is comparatively larger $(b=4.36-4.85: 5.00-5.14)$. Also, the tail is comparatively shorter $(c=8.19$ 9.09: 6.56-7.50).

Intra-population variation in species of the genus were reported previously for Madagascar (Van Waerebeke, 1973). That author found two forms of A. dispar that differ only in the measurements and have the same morphology, a similar to the case recorded in the present work. However, for $A$. triangularis he found another form that differs only in the alignment of the ornamentation of eggs and the lips of the vulva are more prominent, whereas measurements did not vary. Hunt (1981) reported variation for A. horridospina with the varieties typica and brevialata. They differ in the length of the body, lateral alae and esophagus.

\section{ACKNOWLEDGEMENTS}

We are very indebted to the colleagues Elier Fonseca, Gunnary León and the undergraduate student Facundo Alvarez, from the University of Havana, for their help during field work. To MSc. Yamir Torres (Instituto de Ecología y Sistemática) and Dr. Alejandro Barro from the University of Havana for the support with the micrographs. We also thank Dr. Luis F. de Armas (Institute of Ecology and Systematics) for review of the manuscript. This work was financed by IDEAWILD and the project "Zoological Collections, their Conservation and Management" of the Ministry of Science, Technology and Environment, Cuba. 


\section{LITERATURE CITED}

Adamson, M. and D. Van Waerebeke. 1992. Revision of the Thelastomatoidea, Oxyurida of invertebrate hosts III. Hystrignathidae. Syst. Parasit. 22: 111-130.

Artigas, P. 1926. Nematodes de invertebrados. Bol. Biol., Sao Paulo 1: 1-13.

De Man, J.G. 1884. Die frei der reinen Erde und in sussen Wasser Lebenden nematoden neiderlandischen fauna, Eine Systematische Faunistische Monographie. Leiden, 206 pp.

García, N. y A. Coy. 1995. Nemátodos parásitos de artrópodos de la Sierra de los Organos, Cuba. AvaCient 14:26-30.

García, N., L. Ventosa y J. Morffe. 2009. Especie Nueva de Artigasia (Thelastomatoidea: Hystrignathidae) de Pico La Melba, Holguín, Cuba. Solenodon 8: 8-11.

Hunt, D. J. 1981. On Artigasia horridospina n. sp., Longior semialata n. sp., Mentecle magnifica n. sp., Paraxyo ensicrinatus n. sp. (Oxyurida: Hystrignathidae) and Pulchrocephala? pulchrocephala Travassos, 1925 (Oxyurida: Pulchrocephalidae). Syst. Parasitol. 3: 33-52.

Jex, A. R., T. H. Cribb and M. A. Schneider. 2004. Aururoides queenslandensis n. sp. (Oxyurida: Thelastomatoidea), a new nematode from Australian Panesthiinae (Blattodea: Blaberidae). Syst. Parasitol. 59: 65-69.

Théodoridès, J. 1955. Contribution a l'etude des parasites e phorétiques de colèoptéres terrestres. Vie et Milieu, Supplement 4.310 pp.

Théodoridès, J. 1958. Artigasia paulianai Théodoridès, 1955 var. joliveti nov. (Nematoda: Oxyuroidea: Thelastomatidae) parasite d'un Coleoptere Passalide. Explor. Parc Nat. Albert, Congo Belge, ser. 2, 6:21-24.

Travassos, L. y G. R. Kloss. 1957a. Nématodeos de invertebrados. 1. nota. Rev. Brasil. Biol. 17(3): 295-302.

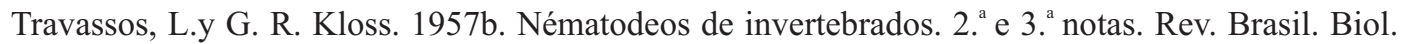
17(4): 467-477.

Travassos, L. y G. Kloss. 1958. Sobre a fauna de nematodeos dos coleopteros Passalidae da Estaçao Biologica de Boracéia. Arq. Zool. Sao Paulo 11:23-57.

Van Waerebeke, D. 1973. Les oxyuroides associes aux Passalidae à Madagascar. Cah. ORSTOM, sér. Biol. 18: 3-43. 